\title{
The Impact of Journal Writing on Cycle Two EFL Students Writing Achievement
}

\author{
Mona Tahseldar
}

\begin{abstract}
Although writing proficiency is a must nowadays, it seems to be challenging for many EFL students. Being limited to timing and grade, students in Beirut Lebanon schools suffer from the writing periods and process. Cycle two students avoid writing in English as they lack the basic writing skills that help them meet the growing demands of this skill. As a potential solution, this study investigated whether or not EFL learners could overcome their writing difficulties by engaging them in journal writing technique. Sixty-two students from grades 4,5and 6at a private school in Beirut Lebanon were enrolled in this study. The participants were motivated to write journals three times a week for 12 weeks. The teacher used to collect students'journals every Friday and turn them back on Mondays with her comments written on every student's journal. Most of the common mistakes were explained and discussed by the teacher before distributing students' copy books. Moreover, students had to fill in an attitude questionnaire of five questions derived from literature to evaluate their improvement and attitude toward EFL journal writing after conducting the journal writing technique. For additional data, the teacher and the researcher observation notes served in exploring more details about students' attitude toward their journal writing experience. The findings indicated significant improvement in students' writing posttest scores compared to their pretest scores and impressive students' attitude toward EFL writing. Thus, results showed that journal writing can be taken into educators' consideration as an extensive technique to enhance learners' writing skill and foster their EFL writing attitude.
\end{abstract}

Keywords: Journal writing, writing skill, student attitude, free writing, fluency

\section{Introduction}

A wide range of jobs requires the production of written documentation, visual/text presentations, technical reports and electronic messages. The proliferation of electronic and wireless communication in everyday life demands advanced writing skills as never before. Many reports by the National Commission on Writing $(2004,2005)$ revealed that writing proficiency has now become an essential requirement which affects-hiring and promotion decisions for recruitment. Thus, the demand for writing proficiency is not limited to schooling but to many other life style communications. Based on Lagan's (2000) who explored whether learners can grow out of their writing difficulties by engaging them in journal writing, he concluded that the more of writing practice, the better students will write. Logically, it can be expected that the first pieces of journal writing by an average student are not enough, but with the teacher's facilitation and continuous journal writing students can achieve fluency and the habit of EFL writing. Furthermore, Lagan (2000: 14) found that "Journal writing can help remove the embarrassing situation in which students often find themselves deficient in ideas and encourage fluency so learners can write better and better day by day". Similarly, the journal writing activities to Hamp and Heasley (2006:5) provided learners with more opportunities to freely write about topics that lie within their interests and whenever they deemed convenient. The above-mentioned authors believed that the most obvious way to be a good writer is by practicing frequent writing.

\section{Problem Statement}

Learning English as a foreign language is not an option for EFL young students in Lebanon, it is a must. Along with EFL skills, the writing skill is a predictor of the academic acquisition of a foreign language. Yet English writing, for a number of EFL learners, appears to be challenging. Although the language barrier affects students' understanding and performance across all subject areas, the area in which students experience the most difficulty is writing E. As an EFL teacher, who has been involved in teaching/learning process for more than thirty five years, it was obvious that in many Lebanese schools and universities a large number of students are unable to write at the basic levels, organization, required by EFL Lebanese curriculum.

Seemingly, it is not the case in Lebanon only, it is a global problem. According to Richards and Renanya (2002, as cited in Layeghi 2011) "There is no doubt that writing is the most difficult skill for second language learners to master" ( $p$. $33)$. Yet, it is generally construed from the published articles that EFL learners do not write as well as we think they should as their writing is not well organized, full of grammatical, and/or spelling mistakes. The reasons for inability to write well enough to meet teachers' expectations are many and varied (Layeghi, 2011).In this respect, Chanderasegaran (2002:14) stated that some students take much longer than others to write the required task, thus cannot finish their writing in class.

For instance, one of the main objectives of writing instruction is to enable the students to write well. In that line, many educators as Hillocks 1986; Ping, 2000; Rijaarsdam et al., 2005, consider that success in writing is a reflection of students' abilities concerning ideas, vocabulary, grammar, mechanics, sentence structure, coherence, unity and organization. The Nation's Report Card: Writing 2007 (2008) declared that $42 \%$ of the English Language learners in USA scored below the writing basic skills because they struggled with style techniques, vocabulary and sentence formation. Accordingly, Francis et al., (2006) found that many students lack the skills to meet the required writing standards, while Persky et al., (2003)claimed that $70 \%$ of students in who scores 4-12 are low-achieving writers, and to ACT(2005) nearly one third of high school graduates are not ready for college-level English composition courses. ,'Many colleagues and educators in Beirut noticed is that EFL students practice writing occasionally during EFL classes which makes sense that without continual practice 


\section{International Journal of Science and Research (IJSR) \\ ISSN (Online): 2319-7064}

Index Copernicus Value (2016): 79.57 | Impact Factor (2017): 7.296

the writing skills will be slow to develop. Realizingan overall average of less than $50 / 100$ score, about $16.12 \%$ of cycle two private school students in Beirut, Lebanon were below the passing grade in the writing midterm exam signaled a serious problem that EFL students encounter in an essential language skill. Such a percentage of failures urged educators to look for solutions to overcome the students' low writing levels. Thus, the main goal behind this study was to help students enhance their writing achievement and attitude.

As a result, we find teachers struggling for strategies to help EFL students develop their writing skills. It is the case of most EFL teachers in Lebanon who suffer of students' inability to write a paragraph that satisfies the basic requirements of writing. Many studies suggested a number of strategies and techniques that can be used to assist EFL teachers teach writing, like journal writing.

\section{Study Questions}

The study was guided by this main question; what is the impact of journal writing on cycle two students' EFL achievement and attitude?

To answer the main question, the study was guided by the following sub questions:

1) What is the effect of journal writing on the writing performance of cycle 2 students after the intervention of the journal writing technique in EFL classes?

2) Is there a significant difference in the writing performance of cycle 2 students attributed to gender after the intervention of journal writing technique in EFL classes?

3) What is the students' attitude toward EFL writing after the journal technique is implemented as a part of the English language curriculum?

\section{Purpose}

The study aimed to investigate the effect of journal writing on cycle two EFL learners' writing achievement and their attitude toward journal writing. The purpose of conducting journal writing technique in cycle two classes was to support students surpass their difficulties and so on in writing. Thus, it highlights students' abilities and attitudes toward practicing writing freely away from fears of being restricted to specific time and of being graded. Similarly, practicing journal writing explains the effect of training students to write freely on their writing scores, their attitudes toward writing and their interest to continue writing journals.

\section{Significance of the study}

This study will provide students with a journal writing technique in order to practice writing freely, and EFL teachers to experience this writing technique in language teaching. Since the use of journal writing is not common in many schools, it will be interesting to see how students become independent writers after the intervention of journal writing. Thus, the findings of this study might encourage teachers in the Lebanese context to use the journal writing technique in teaching writing as well as including such a technique in the Lebanese foreign language curriculum.

\section{Literature Review}

\section{Definitions}

An extensive review of the literature has revealed many definitions for journal writing, when the idea of 'journal writing' appeared as a reaction towards the traditional methods of teaching writing. Brogoff, (1975); Bailey's, (1990); Richards, (1992); Porter et al.,(1996); Hiemstra, (2001); Johnson, (2002); Curtis \& Bailey, (2009); Barjesteh et al. (2011); Zittoun \& Gillespie,( 2011) Barjesteh et al., (2011) Lipnevich, A.A. \& Smith, J.K. (2008), definitions considered journal writing as a kind of free-writing activity where writers write with no fears of being evaluated. Hiemstra (2001) found journals as a learners' record of their thoughts, feelings and reactions to experiences they passed through. Likewise, journals have gained more importance in the literature not only for their different uses but mainly for the benefits they may fulfill. Barjesteh et al., (2011) claimed that journal writing was a beneficial method for it helped students to write more. Accordingly, journals were considered by Absalom \& Leger (2011), as a tool to reflect learners' experiences, or to develop their writing skills and their creativity.

Concerning writing fluency, Brand \& Brand (2006) defined the general meaning of fluency in writing as completing a technique or a task effortlessly. Other researchers like Casanave, (2004); Mac Gowan-Gilhooly, (1991)described writing fluency by using terms such as writing without hesitation, fearless to make mistakes, and expressing ideas smoothly. In terms of writing fluency, Lannin (2007) stated that some researchers defined writing fluency as "cohesiveness and coherence of ideas in the writing, aided by syntactic structures that enable a reader to easily move thorough the text" (p. 4). However, Elbow \& Belanoff, (2000) found this definition not appropriate for the purpose of free writing because free writing is usually considered as writing with no focus on accuracy. Thus, free writing has been more related to fluency term or flow of ideasterm, which meant writers usually forget about time and score. Moreover, Casanave (2004) stated in her book that "writing fluency is related to 'writers' ability to produce a lot of language without excessive hesitations, blocks, and interruptions" (p. 67).In the same way, writing fluency to Patterson (2014), is a flow of language ideas without any kind of correction. Mac-Gown-Gilhooly (1991), McDonough \& McDonough, (1997) and Rubin (2003) found that when fluency was stressed over accuracy in classrooms, learners showed more self-confidence and less worries for they were able to develop more fluency in generating ideas compared to when they were corrected on form. Likewise, learners to Bagheri \& Pourgharib, (2013) must have the freedom to write without worrying about form. Hence, teachers should not correct linguistic errors in students' journals but respond to the message in a meaningful way.

A large part of the literature was devoted to the description of this issue, (Richard \& Lockhart, 1996; Lagan, 2000; Mare fat, 2002; Hamp \& Heasley, 2006; Kirkgoz, 2009). Elbow (1998) stressed the fact of not editing journals that help increasing students' fluency and their ability to evaluate their own performance so they become independent learners; able to take the responsibility of their own learning, monitor

\section{Volume 7 Issue 5, May 2018




\section{International Journal of Science and Research (IJSR) ISSN (Online): 2319-7064}

Index Copernicus Value (2016): 79.57 | Impact Factor (2017): 7.296

their progress, and the strategies they use which will eventually result in developing their writing skills.

Thus, students need praise and encouragement to boost their success more than teachers' corrections and feedback no matter what level they are (Bluestein, 2004; Lipnevich \& Smith, 2008; Schunk \& Zimmerman, 2012). A senior research for the Educational Testing Service (Diedrich, 1974) claimed that praising students' writing improved their writing skills more than correcting their errors. Moreover, Goldstein,(2004); and Ferris,( 2002) hypothesized that teacher-written feedback was seen by both teachers and students as necessary in the writing process, while others claimed that it had a bad effect on students' writing freely (Truscott, 2007; Truscott \& Hsu, (2008). Similarly, Truscott (2004) argued that teacher's correction feedback had a negative effect on students' writing fluency, which affected their overall writing. To avoid this deficiency Ferris, (2004) advised teachers to provide students with indirect feedback, which we focused on in our study. Consequently, many researchers concluded that praise is an indirect feedback that improved students' self-esteem, confidence and writing performance such as Alber \& Haward, (2000), and Daiker, (2011)who added that praise worked more with low achievers and motivated them to write more. On the other hand, some researchers as Corpus, Ogle \& Love-Geigner, (2006), Kluger \& Denisi, (1996)argued that praise may end up with students losing their motivation and interest in writing if it is not given in the right way and to the right person or else it definitely will boost students' motivation, achievement and self-esteem deemed

To sum up, Journals were seen as good examples for writing progress when students were praised and wrote without fear of being graded. Nevertheless, Haimovitz \& Corpus, (2011) reported that that most of the studies that showed the effectiveness of journals on students attitude and achievement were related to adults and few discussed the topic in relation to children.

\section{Studies}

Previous Studies' findings suggested that keeping journals improved students' writing achievement, fluency, grammar and vocabulary skills. Most of the studies focused on journal writing for example, in Indonesia, Wafa, Syafei, \& Riyono (2010) investigated whether there was a significance progress on 38 G10 EFL students' writing abilities after regular journal writing at SMANI Jekulo Kudus. Results showed that when students' journal writing was not restricted to a specific time or scores, their scores increased. Moreover, the study concluded that students' writing scores were increased and that journal writing was considered an effective tool for improving students' writing achieve mental though they kept having grammar and vocabulary mistakes. Ningrum, Rita \& Hastini (2013) examined the effect of journal writing on 52 Ggrade10EFL students' writing texts in Indonesia. They used pre post tests where students were asked to write about something that happened to them for 8 weeks on daily basis. Results showed that students were convinced that using journals improved their writing skills and $48 \%$ of them got higher scores on the posttest. Furthermore, Safitri (2011) conducted an experimental study to know the effect of journal writing on G8 students' writing achievement in Indonesia. The study results showed that journal writing affected the experimental students' writing achievement significantly.

Similarly, Tuan (2010), conducted a study on 85 Vietnam college students to find out whether journal writing enhances students' accuracy fluency and motivation. Results revealed that the experimental group students were more motivated and showed fluency and accuracy in writing.

Findings of many studies discussed journal writing effect on students' attitude toward EFL writing skills showed positive results between the two. Using journal writing technique and an attitude questionnaire, Allison (1998) investigated the effect of journal writing on38students' attitudes in an English language course at the National University of Singapore. The findings showed disclosed positive students' attitude to the use of journals as a writing activity. Many other researchers investigated students' attitude in relation to journal writing, for instance, Marefat (2002) study results conducted on 80 Persian speaking undergraduate students, revealed that journal writing was a useful experience for students as they enjoyed the activity after they received intensive training to help them participate fully in the process. In a more recent study, Huang (2010) examined the effect of journal writing on 8 Thai EFL students' writing fluency, writing quality and writing confidence. A process of comparing the pre- posttest scores and the attitude test indicated that journal writing helped EFL college students increase their writing fluency and their confidence as a result of journal writing.

From investigating fluency achievement and attitudes, to investigating accuracy, fluency and unity where Fitriana (2009) examined the experience ofG9Indonesian learners' language proficiency as reflected in their journals. The, Fitriana (2009)study results revealed that all students through practicing journal writing could develop their sentence structure, linguistic features, coherence, cohesion and unity; however, they continued to have problems with vocabulary and grammar. Similarly, Like Fitriana (2009), Tuan (2010) conducted a study on 85 Vietnam college students to find out whether journal writing enhances students' accuracy, fluency, and motivation. Results revealed that the experimental group students were more motivated, fluent, and accurate in their writing production.

Contrary to the above study studies, Hidayat (2011) experimented two groups of learners, with an aim of studying the effect of journal writing on students' correct usage of the past tense. Using a pre-test and a post-test, it was found that the experimental students were better in using the past tense in their journals, with a conclusion that emphasized journal writing as an effective method to improve students' grammar in writing .Similar to the abovementioned studies, Barjesteh, Vaseghi \& Gholami (2011) results showed that journal writing increased students' selfconfidence, writing fluency and attitudes towards writing while students' grammatical accuracy decreased, after implementing journal writing on 44 EFL Iranian college students.

\section{Volume 7 Issue 5, May 2018 www.ijsr.net}




\section{International Journal of Science and Research (IJSR) \\ ISSN (Online): 2319-7064}

Index Copernicus Value (2016): 79.57 | Impact Factor (2017): 7.296

Like Fitriana (2009) and Hidayat (2011), Ningrum, Rita \& Hastini (2013) investigated the effect of journal writing on the writing texts of 52 EFL G10 Indonesian students from two classes. They used pre post-tests where students were asked to write about something that happened to them for 8 weeks on daily basis. Results showed that $48 \%$ of the class got higher scores on the post-test and students believed that using journals improved their writing skills. Furthermore, Safitri (2011) wanted to know the effect of writing a journal on G8 students' writing achievement in Indonesia. An experimental design was used with an experimental class and a control class. Results showed a significant effect of writing a journal on students' writing achievement.

Concerning the impact of journal writing on students' vocabulary growth, knowledge and learning strategies, Kirkgoz (2009) conducted a study on 32 first year Turkish undergraduate students who were undergone a procedure of writing journals 3 times a week for 14 weeks. Results showed that students used the keyword technique, grouping similar words visualizing, making associations, and making use of linguistic knowledge in their writings, which proved that through practicing journal writing Kirkgos could achieve what he aimed at in his study. In a more recent study, Huang (2010) investigated the effect of journal writing on 8 Thai EFL students' writing fluency, writing quality and students' writing confidence. A process of comparing the pre- posttests scores and the attitude test indicated that journal writing helped EFL college students increase their writing fluency and their confidence as a result of journal writing. Similar to the above studies Barjesteh, Vaseghi \& Gholami (2011) results showed that journal writing increased students' self-confidence, writing fluency and attitudes towards writing while students` grammatical accuracy decreased, after implementing journal writing on 44 EFL Iranian college students.

As seen in the literature review above, few studies have investigated the effect of journal writing on cycle two students' achievement and attitude. Hence, the present study intends to add to the literature a study about journal writing effects on cycle two EFL learners writing achievement and attitude.

\section{Research Methodology}

This study can be considered as a mixed method design where the qualitative part isa thematic coding of the observation and discussion, while the quantitative part is the pre posttest scores and the analysis of the four Likert scale attitude questionnaire. Thus, it is an experimental quantitative qualitative study, with no control group. It describes the differences in students' pre \ post writing scores and their attitudes toward EFL writing after the intervention of journal writing technique in cycle two EFL writing classes for twelve weeks.

\section{Participants}

62 cycle two students from a private school in Beirut Lebanon, (39 females and 23 males) participated in this study. The participants were distributed on grades 4,5 , and 6 as shown in table 1 figure 1 . They shared the same negative attitude and the same writing proficiency level. The students' pretest scores showed evidently that the majority of cycle two students suffered of grammar mistakes, vocabulary gaps, shortage of ideas, and writing fluency. The average age of the participants ranged between 9 and 13 years, which applies to the official age requirements assigned by the ministry of education. Thus, the reason behind this selection was students' weakness in the writing skills and their negative attitude toward EFL writing classes. The participant students were motivated by their teacher to write three journals a week about topics of their choice. The teacher and the researcher recorded observation notes in terms of students' opinions, reactions, comments, answers, feedback and attitudes during the intervention process, which helped in exploring students' level of development. Thus, the effect of journal writing technique on the learners' writing scores as well as their attitudes were recorded through pre and posttests, observations and filling out a four Likert scale attitude questionnaire.

Table 1: Frequency and percentages of participants

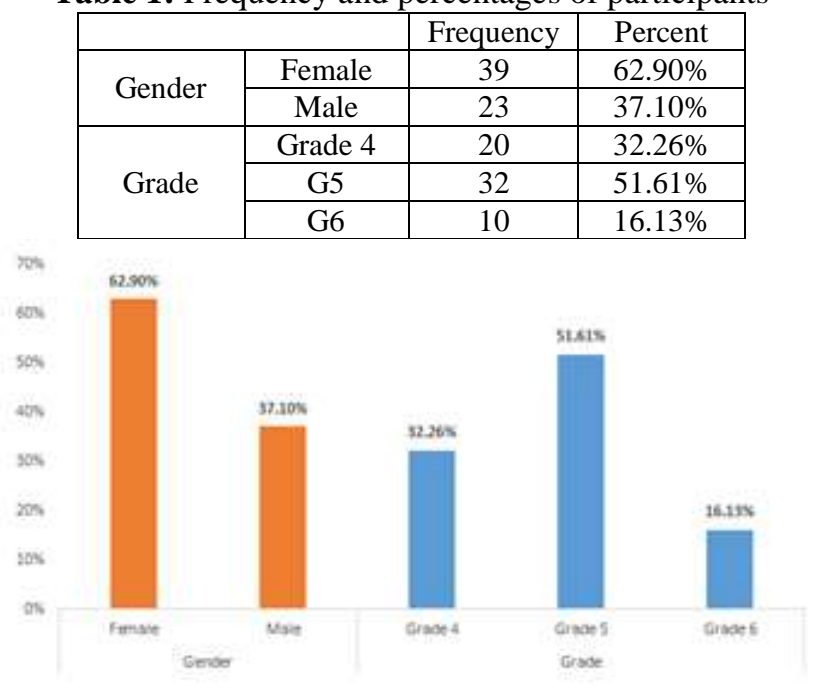

Figure 1

As noticed in table 1and figure 1, the participants' distribution can be described as follows:

- 62 participants in the study

- 23 males $(37.10 \%)$

- 39 females $(62.90 \%)$

- Grade 4: 20 students (32.26\%)

○ 9 males

○ 11 females

- G5: 32 students (51.61\%)

○ 13 males

○ 19 females

- G6: 10 students (16.13\%)

○ 1 males

○ 9 females

As seen above, (table 1 figure 1), 62 cycle two students participated in the study. The participants were from grades 4 (20 students), 5 (32 students) and 6 (10 Students). The participants were distributed according to gender as follows: 23 males $(37.10 \%)$ and 39 females $(62.90 \%)$. The above results showed as well that Grade 4 participants constituted $(32.26 \%)$ of the sample (9 males and 11 females), G5 


\section{International Journal of Science and Research (IJSR) \\ ISSN (Online): 2319-7064}

Index Copernicus Value (2016): 79.57 | Impact Factor (2017): 7.296

participants constituted $(51.61 \%)$ of the sample (13 males and 19 females) and G6 participants constituted (16.13\%) of the sample (1male and 9 females).

\section{Instrumentation}

Cycle two students' writing midterm and final scores were considered as pretest and posttest instruments to measure students' writing proficiency level before and after implementing the journal writing technique in EFL classes. In other words, the initial writing proficiency level of the whole population of cycle two students was investigated through their midterm writing scores as a pre- test, and their final exam writing scores as a post-test to assess the impact of journal writing on their writing. Each student in the study needed to have a note book for journal writing. Students were encouraged to write their journals three times a week, for twelve weeks. It was noticed that students' writings focused on their feelings, emotions, reactions and attitudes toward their real life experiences. The researcher observed all Monday discussion sessions and checked all praise comments written by the teacher in the students' copybooks. During Monday sessions, the teacher used to write samples of students' mistakes like tenses, subject verb agreement, sentence structure, shortage of vocabulary, fluency on the board and discussed them with the students. Regarding all what was happening the teacher and the researcher kept a journal to record the changes occurred in students' writing, reactions and attitudes toward writing.

To examine the students' interest and attitude toward writing journals after the intervention, cycle two students had to fill a four-point Likert Scale questionnaire ranging from "strongly agree" to "disagree" questions, prepared by the researcher based on literature. For more details concerning students' attitude, the observation technique was analyzed to collect data through the teacher and researcher's notes taken during the discussion periods and meetings.

\section{Procedure}

The study was conducted on 62 cycle two students from a private school in Beirut Lebanon during the second semester of school year 2015/2016. In the beginning, and after we got the school administration approval to conduct the study, the students were informed about the study and each one received a consent letter to be signed by his parent. For an effective implementation of the journal writing technique, Ningrum, Y., et al. (2013), Safitri,Y. (2013), Rubin ,(2003); Montgomery, (2001); and Cooper\& Kiger, (2003), suggested steps were followed. Thus, the researcher met the teacher that conducted the technique many times before starting the intervention and explained the procedure to be followed including how to guide, direct, facilitate, motivate, follow up and assess students' writing tasks. In the opening stage, the researcher explained the idea of journal writing to cycle two students and the teacher wrote a sample journal in the classroom. Then, with the help of students, the teacher could set how frequently they have to write their journals and how often they have to turn in their journals so that she can read and comment on them. Moreover, students were informed that they were free to write about any topic they liked and that Monday group discussions were to discuss their common mistakes in journal writing. Not forgetting, that their teacher was always there to help them solve the problems they faced during writing their journals. Thus, the implementation started by motivating the students in grades four, five and six to keep a notebook for writing their journals three times a week and to express themselves in different ways. To boost students' motivation, students were promised that their journals will not be graded or evaluated, and that their participation in the study will be kept confidential. For twelve weeks, the teacher had to collect the journals every Friday to turn them back on Mondays with her encouraging comments for more self-expression and more writing. Some praise comments were about interesting topics, and topics that the teacher liked to hear more about. However, the teacher did not comment on the vocabulary employed or grammatical mistakes for the main goal was continuous writing. Due to the students' motivation to read their journals in class, the teacher had to arrange a schedule so that every student could have the chance to read one of his journals in class and discuss it with his classmates and teacher. The in-class weekly discussion was considered an indirect monitoring for students' mistakes that did not take more than 50 minutes a week. Furthermore, conversations took place between teacher, researcher and the students to discuss their difficulties, attitudes and future plans to develop their journals. More about researcher's follow up, it was obvious that attending three different Monday classes every week was beneficial to collect data about students' attitude toward the writing classes and the teacher's performance. Weekly meetings were also held with the teacher to discuss the notes and comments jotted down in a notebook assigned for the task and the development of students' writings and attitudes. SPSS, a Windows based program that can be used to carry out data entry and to create tables and graphs, was used for data analysis that helped comparing between pre-test and post-test means, standard deviation, percentages, modes, and coefficients of students' scores. Finally, using SPSS, afforded enough statistical analysis to evaluate the students' language improvement and their attitude tested through the attitude questionnaire.

\section{Results}

The purpose of the study was to determine whether journal writing technique would lead to the development of cycle two students' writing scores, males and females and their attitude toward the writing skill. The number who actually participated in the study was statistically a significant number that in turn would allow generalized comments to bead dressed. A number of sixty two EFL cycle two students, males and females, from a private school in Beirut were enrolled in this study. Three types of measures were used to collect data: students' pretest and posttest writing scores, the attitude questionnaire results, and the teacher's and researcher's notes taken during observation. In order to investigate students' attitudes toward journal writing technique and its effect on students' writing achievement after 12 weeks of intervention. SPSS was used for data analysis to answer the study questions.

\section{Descriptive Statistics for Scores}

Descriptive statistics are used to describe the basic features of the data in a study, and provide simple summaries about the sample and the measures. Together with the simple

\section{Volume 7 Issue 5, May 2018 www.ijsr.net}




\section{International Journal of Science and Research (IJSR) \\ ISSN (Online): 2319-7064}

Index Copernicus Value (2016): 79.57 | Impact Factor (2017): 7.296

graphics analysis, they form the basis of virtually every quantitative analysis of data. Thus, the descriptive statistics are used to present quantitative descriptions in a manageable form that helps us simplify large amounts of data in a sensible way, where each reduces lots of data into a simpler summary.

To answer the first question of the study, what is the effect of journal writing on the writing performance of cycle two students after the intervention of the journal writing technique in EFL classes? The following statistical operations were computed.

\section{Student Scores}

Table 2: Grade 4 prelpost scores

\begin{tabular}{|c|c|c|c|}
\hline Gender & Class & Pretest & Posttest \\
\hline Male & Grade4 & 75.00 & 70.00 \\
\hline Male & grade 4 & 65.00 & 65.00 \\
\hline Male & grade 4 & 60.00 & 75.00 \\
\hline Male & grade 4 & 45.00 & 52.50 \\
\hline Male & grade 4 & 75.00 & 75.00 \\
\hline Male & grade 4 & 55.00 & 62.50 \\
\hline Male & grade 4 & 65.00 & 72.50 \\
\hline Male & grade 4 & 65.00 & 55.00 \\
\hline Male & grade 4 & 60.00 & 65.00 \\
\hline Female & grade 4 & 75.00 & 72.50 \\
\hline Female & grade 4 & 60.00 & 67.50 \\
\hline Female & grade 4 & 60.00 & 75.00 \\
\hline Female & grade 4 & 65.00 & 72.50 \\
\hline Female & grade 4 & 55.00 & 62.50 \\
\hline Female & grade 4 & 65.00 & 75.00 \\
\hline Female & grade 4 & 55.00 & 57.50 \\
\hline Female & grade 4 & 50.00 & 57.50 \\
\hline Female & grade 4 & 70.00 & 65.00 \\
\hline Female & grade 4 & 65.00 & 85.00 \\
\hline Female & grade 4 & 60.00 & 55.00 \\
\hline
\end{tabular}

In table 2 we notice a clear increase in the posttest scores of 13 out of $20 \mathrm{G} 4$ students and a decrease in 5 students' grades, while the remaining two students' scores are the same in both pre and posttests. Consequently, the majority of grade 4 students' scores in EFL writing improved after conducting the journal writing technique for 12 weeks, which proves that the method implemented was successful for grade 4 . What is remarkable is that 3 students' scored an increase less than 10 grades and 4 students could achieve an increase of 10 to 20 grades in the post test, while the remaining 6 posttest scores increased 7 grades compared to their pre test scores respectively.

Table 3: G5 prelpost scores

\begin{tabular}{|c|c|c|c|}
\hline Gender & Class & Pretest & Posttest \\
\hline Male & G5 & 60 & 90 \\
\hline Male & G5 & 55 & 72.5 \\
\hline Male & G5 & 80 & 85 \\
\hline Male & G5 & 60 & 65 \\
\hline Male & G5 & 55 & 60 \\
\hline Male & G5 & 25 & 42.5 \\
\hline Male & G5 & 47.5 & 38.75 \\
\hline Male & G5 & 85 & 87.5 \\
\hline Male & G5 & 55 & 80 \\
\hline Male & G5 & 57.5 & 75 \\
\hline Male & G5 & 65 & 85 \\
\hline Male & G5 & 55 & 62.5 \\
\hline
\end{tabular}

Volume 7 Issue 5, May 2018 www.ijsr.net

Licensed Under Creative Commons Attribution CC BY

\begin{tabular}{|c|c|c|c|} 
Male & G5 & 70 & 87.5 \\
\hline female & G5 & 65 & 65 \\
\hline female & G5 & 70 & 80 \\
\hline female & G5 & 47.5 & 50 \\
\hline female & G5 & 90 & 90 \\
\hline female & G5 & 50 & 65 \\
\hline female & G5 & 55 & 65 \\
\hline female & G5 & 85 & 72.5 \\
\hline female & G5 & 60 & 75 \\
\hline female & G5 & 50 & 55 \\
\hline female & G5 & 70 & 77.5 \\
\hline female & G5 & 80 & 90 \\
\hline female & G5 & 25 & 57.5 \\
\hline female & G5 & 45 & 50 \\
\hline female & G5 & 45 & 70 \\
\hline female & G5 & 50 & 75 \\
\hline female & G5 & 65 & 75 \\
\hline female & G5 & 55 & 55 \\
\hline female & G5 & 67.5 & 77.5 \\
\hline female & G5 & 65 & 55 \\
\hline
\end{tabular}

In table 3 we notice a performance growth in G5 students' writing achievement. The table shows a clear increase in the posttest scores of 26 out of 32 G5 students and a decrease in 3 students' scores, while the remaining 3 students' scores stayed the same in both pre and posttests. Consequently, the majority of G5 students' scores in EFL writing has increased after conducting the journal writing technique for 12 weeks, which proves that the method implemented was successful for G5. It is important to mention that 14 of G 5 students' post test scores have increased 10 scores and above to reach 25 scores compared to their pre test scores.

Table 4: G6 pre/post scores

\begin{tabular}{|l|l|l|l|}
\hline Gender & Class & Pre_test & Post_test \\
\hline Male & G6 & 70.00 & 65.00 \\
\hline Female & G6 & 40.00 & 47.50 \\
\hline Female & G6 & 75.00 & 82.50 \\
\hline Female & G6 & 60.00 & 67.50 \\
\hline Female & G6 & 75.00 & 87.50 \\
\hline Female & G6 & 65.00 & 60.00 \\
\hline Female & G6 & 32.50 & 52.50 \\
\hline Female & G6 & 30.00 & 57.50 \\
\hline Female & G6 & 65.00 & 80.00 \\
\hline Female & G6 & 65.00 & 55.00 \\
\hline
\end{tabular}

In table 4 it is clear that there is an increase in the posttest scores of 7 out of 10 G6 students, yet 3 students' scores decreased. We notice as well that 3 students got below the average 50/100 in the pretest while in the post test only one student failed although his grade increased 7 scores (pre $40 / 100$, post 47/100). Consequently, the majority of G6 students scores in EFL writing developed after conducting the journal writing technique for 12 weeks, which proves that the method implemented was successful for G6. The increase in students' post test scores varied between 7.5 scores and 27 scores in comparison to their pre test scores.

For a detailed explanation to answer the first study question in details, simple compare mean test was used just to calculate the mean, standard deviation, mode, minimum and maximum of students' writing pre-test and post-test scores. 


\section{International Journal of Science and Research (IJSR) \\ ISSN (Online): 2319-7064}

Index Copernicus Value (2016): 79.57 | Impact Factor (2017): 7.296

Table 5: General comparison between pre-post tests

\begin{tabular}{|c|c|c|}
\hline & Before & After \\
\hline Mean & 60.20 & 68.13 \\
\hline Mode & 65.00 & 65.00 \\
\hline SD & 13.48 & 12.53 \\
\hline Minimum & 25.00 & 38.75 \\
\hline Maximum & 90.00 & 90.00 \\
\hline CV & $22.39 \%$ & $18.40 \%$ \\
\hline
\end{tabular}

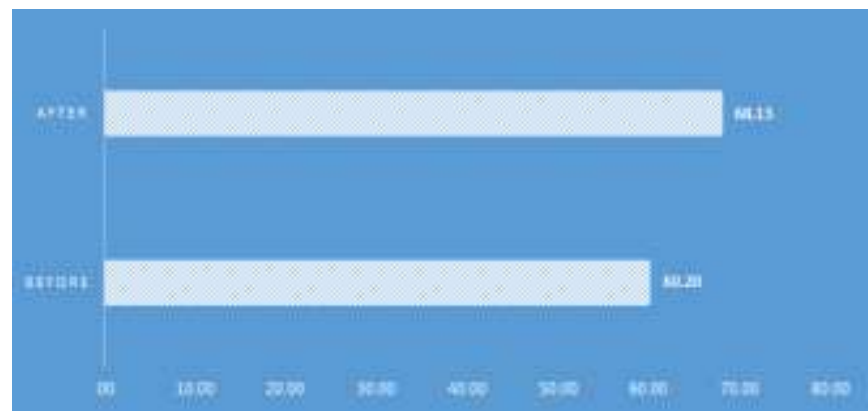

Figure 2

Table 5 and figure 2 reveal the difference between mean, standard deviation, mode, minimum and maximum of all students' scores before and after conducting the journal technique. We notice that the mean in the pretest (60.20) has increased to become 68.13, while the mode and the maximum stayed the same 65.00 and 90 respectively. As for the minimum grade in the pretest $(25.00)$, we realize that it has increased to become 38.75. Thus, we can say that the journal technique helped students to have better achievement

More to explain the effect of journal writing technique on cycle 2 EFL students' achievement, we used Paired sample test, which is a parametric test used to compare the results of the same group of respondents. For the interpretation, we compare Sig (Degree of significance) with $\alpha$ (error ratio $=$ $5 \%$ i.e. 0.05). If $\mathrm{Sig}>\alpha \rightarrow$, we consider the difference insignificant and vice Versa.

Table 6: Paired Sample Test Results

\begin{tabular}{|c|c|c|c|c|}
\hline & Mean & SD & \% of variation & Sig \\
\hline Before & 60.20 & 13.48 & \multirow{2}{*}{$13.16 \%$} & \multirow{2}{*}{$\mathbf{0 . 0 0 0}$} \\
\hline After & 68.13 & 12.53 & & \\
\hline
\end{tabular}

As displayed in table 6, there is a significant difference between the pretest and post-test mean scores. Therefore, the difference of the results is significant before and after the implementation of the journal writing technique, and the percentage of improvement is equal to $13.16 \%$ with a level of significance $=0.000<\alpha$ which means that journal writing affected students` writing scores positively. The mean scores for the pre-test and the post- test are 60.20, and 68.13 respectively, which indicates the progress in students' scores after implementing the journal writing technique in EFL classes. For more explanation, the scores before and after implementing journal writing technique by grade level were compared in order to show the level of students' improvement in each of cycle two classes.
Table 7: Differences by Grade Level

\begin{tabular}{|c|c|c|c|c|c|}
\hline & & Mean & SD & $\%$ of variation & Sig \\
\hline \multirow{2}{*}{ Grade 4} & Before & 62.25 & 8.03 & \multirow{2}{*}{$7.43 \%$} & \multirow{2}{*}{0.015} \\
\hline & After & 66.88 & 8.62 & & \\
\hline \multirow{2}{*}{ G5 } & Before & 59.69 & 15.10 & \multirow{2}{*}{$16.82 \%$} & \multirow{2}{*}{0.000} \\
\hline & After & 69.73 & 14.26 & & \\
\hline \multirow{2}{*}{ G6 } & Before & 57.75 & 17.10 & \multirow{2}{*}{$13.42 \%$} & \multirow{2}{*}{0.068} \\
\hline & After & 65.50 & 13.68 & & \\
\hline
\end{tabular}

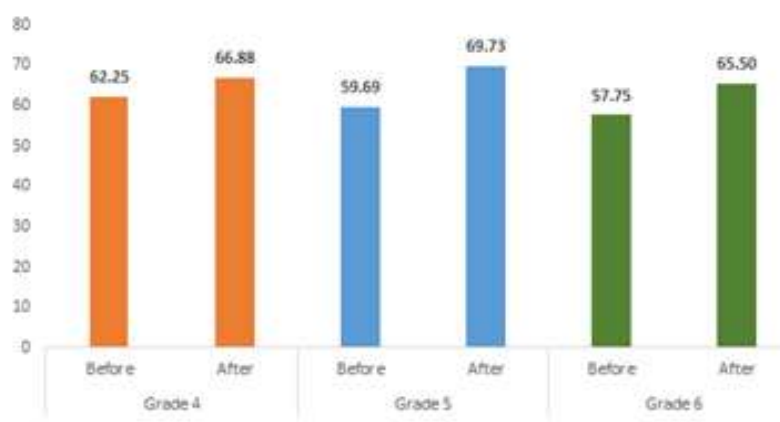

Figure 3
The above table 7 and figure 3 show that the journal technique was very helpful for students in G5 as their mean scores increased around 10 scores while G6 mean scores increased around 7 scores and G4 approximately 4 scores. Accordingly, we can say that most of the participants could achieve better writing scores after implementing the journal writing technique for 12 weeks.

To continue investigating the effect of the journal technique on students' writing scores we intended to calculate $\mathrm{CV}$ (Coefficient of variation), which is an indicator for measuring the dispersion of the values of each variable around the mean. If this value was close to $0.00 \%$ and less than $50.00 \%$, we consider the dispersion low and if it was greater than $50.00 \%$ and close to $100.00 \%$ we consider it high. $(\mathrm{CV}=$ Std. deviation/Mean $)$. Thus pre/ posttest students' scores were classified in two categories: 1- below the average $50 \%$ and 2 - above the average $50 \%$ as shown in the tables below:

Table 8: General scores distribution $\backslash$ below and above $50 \%$

\begin{tabular}{|c|c|c|c|}
\hline \multicolumn{2}{|c|}{} & Frequency & Percent \\
\hline \multirow{2}{*}{ Before } & Below 50 & 10 & $16.13 \%$ \\
\cline { 2 - 4 } & 50 and above & 52 & $83.87 \%$ \\
\hline \multirow{2}{*}{ After } & Below 50 & 3 & $4.84 \%$ \\
\cline { 2 - 4 } & 50 and above & 59 & $95.16 \%$ \\
\hline
\end{tabular}

In general, as shown in table 8, we can deduce that 10 students got below the average 50 over 100 in the pretest, whereas only 3 students in the posttest got below the average which means that the majority of students who got below $50 \%$ were able to achieve above average scores after they practiced the journal writing technique 3 times a week for 12 weeks. 


\section{International Journal of Science and Research (IJSR) \\ ISSN (Online): 2319-7064}

Index Copernicus Value (2016): 79.57 | Impact Factor (2017): 7.296

Table 9: Class Scores Distribution \below and above 50\%

\begin{tabular}{|c|c|c|c|c|c|}
\hline \multicolumn{2}{|c|}{} & \multicolumn{2}{c|}{ Before } & \multicolumn{2}{c|}{ After } \\
\cline { 3 - 6 } \multicolumn{2}{c|}{} & Frequency & Percent & Frequency & Percent \\
\hline \multirow{3}{*}{$\begin{array}{c}\text { Grade } \\
4\end{array}$} & Below 50 & 1 & $5.00 \%$ & 0 & $0.00 \%$ \\
\cline { 2 - 6 } & 50 and above & 19 & $95.00 \%$ & 20 & $100.00 \%$ \\
\cline { 2 - 6 } & Total & 20 & $100.00 \%$ & 20 & $100.00 \%$ \\
\hline \multirow{4}{*}{ G5 } & Below 50 & 6 & $18.75 \%$ & 2 & $6.25 \%$ \\
\cline { 2 - 6 } & 50 and above & 26 & $81.25 \%$ & 30 & $93.75 \%$ \\
\cline { 2 - 6 } & Total & 32 & $100.00 \%$ & 32 & $100.00 \%$ \\
\hline \multirow{3}{*}{ G6 } & Below 50 & 3 & $30.00 \%$ & 1 & $10.00 \%$ \\
\cline { 2 - 6 } & 50 and above & 7 & $70.00 \%$ & 9 & $90.00 \%$ \\
\cline { 2 - 6 } & Total & 10 & $100.00 \%$ & 10 & $100.00 \%$ \\
\hline
\end{tabular}

Table 9 shows the below average and over average students in each of cycle two classes before and after the intervention of the journal writing technique. We notice that in grade 4 only 1 student scored below the average 50 over 100 in the pretest, whereas in the posttest none of them scored below the average. Similarly, in G5, 6 students scored below the average 50 over 100 in the pretest, whereas in the posttest only 2 students scored below the average. In G6, 3 students scored below the average 50 over 100 in the pretest, whereas in the posttest only 1 student scored below the average. In conclusion, we can postulate that the journal technique was very helpful for the majority of cycle two students, which means that the journal writing technique has a positive effect on cycle two students' writing achievement. Consequently, what has been analyzed so far can be considered as an answer to the study question one.

\section{Gender Score Differences}

To answer the second study question: Is there a significant difference in the writing performance of cycle 2 students attributed to gender after the intervention of journal writing technique in EFL classes? A general comparison between gender scores before and after implementing the journal writing technique was done.To compare the results between females and males we used Independent Student test (T-test) which is a parametric test used to compare the means of two independent groups (males and females).For the interpretation, we compared Sig (Degree of significance) with $\alpha$ (error ratio $=5 \%$ i.e. 0.05 ) and if the $\mathrm{Sig}>\alpha \rightarrow$, we consider the difference insignificant and vice Versa.

Table 10: Gender Scores Differences

\begin{tabular}{|l|l|l|l|c|c|}
\hline \multicolumn{2}{|c|}{} & Mean & SD & \% of difference & Sig \\
\hline \multirow{2}{*}{ Before } & Female & 59.68 & 14.11 & \multirow{2}{*}{$2.36 \%$} & \multirow{2}{*}{0.695} \\
\cline { 2 - 4 } & Male & 61.09 & 12.59 & & \\
\hline \multirow{2}{*}{ After } & Female & 67.56 & 11.86 & \multirow{2}{*}{$2.24 \%$} & 0.650 \\
\cline { 2 - 4 } & Male & 69.08 & 13.83 & & \\
\hline
\end{tabular}
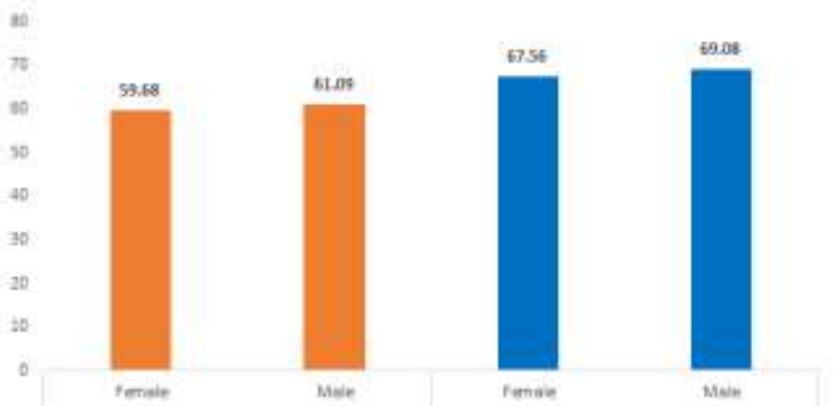

Through table 10 and figure 3 we notice that the scores before the implementation of the journal writing technique were very close between females and males with level of significance $=0.568>\alpha$ which is recommended in the pretest to have insignificant difference between the groups. The female mean scores for pretest are 59.68 while the male mean scores are 61.09. The results show that males achieved better than females in the pretest. On the other hand, the results shown in table 10 and figure 3 prove that both females' and males' mean scores have increased to become 67.56 and 69.08 respectively in the posttest.

Table 11: Gender Scores

\begin{tabular}{|c|c|c|c|c|c|}
\hline & & Mean & SD & $\%$ of variation & Sig \\
\hline \multirow{2}{*}{ Female } & Before & 59.68 & 14.11 & \multirow{2}{*}{$13.21 \%$} & \multirow[b]{2}{*}{0.000} \\
\hline & After & 67.56 & 11.86 & & \\
\hline \multirow{2}{*}{ Male } & Before & 61.09 & 12.59 & \multirow{2}{*}{$13.08 \%$} & \multirow{2}{*}{0.002} \\
\hline & After & 69.08 & 13.83 & & \\
\hline
\end{tabular}

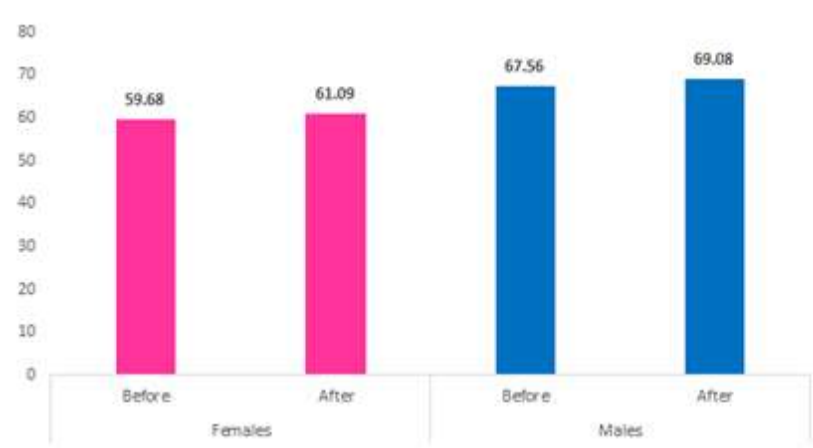

Figure 5

When we compared female and male scores before and after implementing the journal writing technique, the improvement of scores was significant and the percentage of improvement for males $(13.08 \%)$ was better than females (13.21\%). Table 11 shows that male students could achieve better than females after conducting the journal writing technique (males mean score 69.08, females mean score 67.56) which proves that the implemented method was helpful for boys more than girls in general. However, when it comes to compare males and females mean scores in each class, things are different as seen in the tables that follow.

Table 12: Comparison of Gender Scores According to Grade Level

\begin{tabular}{|c|c|c|c|c|c|c|}
\hline & & & Mean & SD & $\begin{array}{c}\% \text { of } \\
\text { variation }\end{array}$ & Sig \\
\hline \multirow{4}{*}{$\begin{array}{c}\text { Grade } \\
4\end{array}$} & \multirow{2}{*}{ Female } & Before & 61.82 & 7.17 & \multirow{2}{*}{$9.56 \%$} & \multirow{2}{*}{$\mathbf{0 . 0 3 3}$} \\
\hline & & After & 67.73 & 9.25 & & \\
\hline & \multirow{2}{*}{ Male } & Before & 62.78 & 9.39 & \multirow{2}{*}{$4.87 \%$} & \multirow{2}{*}{0.261} \\
\hline & & After & 65.83 & 8.20 & & \\
\hline \multirow{4}{*}{ G5 } & \multirow{2}{*}{ Female } & Before & 60.00 & 15.70 & \multirow{2}{*}{$14.03 \%$} & \multirow{2}{*}{0.004} \\
\hline & & After & 68.42 & 12.36 & & \\
\hline & \multirow{2}{*}{ Male } & Before & 59.23 & 14.80 & \multirow{2}{*}{$20.94 \%$} & \multirow{2}{*}{0.001} \\
\hline & & After & 71.63 & 17.01 & & \\
\hline \multirow{4}{*}{ G6 } & \multirow{2}{*}{ Female } & Before & 56.39 & 17.55 & \multirow{2}{*}{$16.26 \%$} & \multirow{2}{*}{0.045} \\
\hline & & After & 65.56 & 14.51 & & \\
\hline & \multirow{2}{*}{ Male } & Before & 70.00 & I & \multirow{2}{*}{$-7.14 \%$} & \multirow{2}{*}{ I } \\
\hline & & After & 65.00 & 1 & & \\
\hline
\end{tabular}

Figure 4 


\section{International Journal of Science and Research (IJSR) \\ ISSN (Online): 2319-7064}

Index Copernicus Value (2016): 79.57 | Impact Factor (2017): 7.296

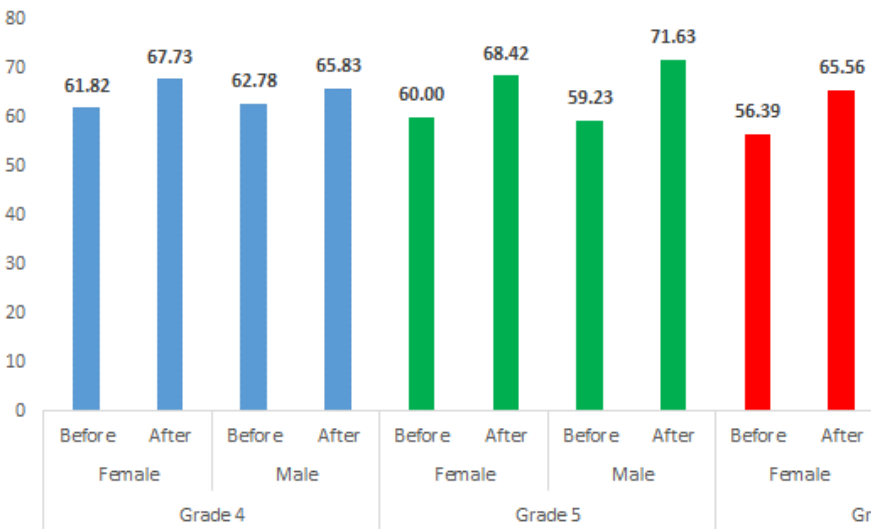

Figure 6

As noticed in table 12, G6 males have no SD since the number of males $=1$

- In grades 4 and 5 there is an improvement in the written production skill for both males and females.

- In grade 4 , male score increased by $4.87 \%$ while female score increased by $9.56 \%$

- In G5, males score increased by $17.01 \%$ while females score increased by $12.36 \%$.

- In G6, there is no improvement in the males score which decreased by $7.14 \%$ while there is an improvement in the females score which increased by $16.26 \%$.

- The improvement of females is better than that of males in grades 4 and 6, while in G5 males' gradesisarebetter.

As a consequence, to answer the second question, we can say that the journal writing technique improved the majority of cycle two female and male students' writing scores, but it helped females more than males in grades 4 and 6 . However, males scored better than females in grade five after the intervention of journal writing for 12 weeks.

\section{-Attitude Questionnaire}

To answer the third question of the study, what is cycle two students' attitude toward EFL writing after the implementation of the journal writing technique for 12 weeks? A four Likert scale questionnaire of five questions was prepared by the researcher through literature to investigate cycle 2 students' attitude and improvement after the intervention of this technique for 12 weeks.

Table 13: Descriptive Statistics for Cycle 2 Learners' Writing Attitude

\begin{tabular}{|c|c|c|c|c|c|}
\hline Questions & $\begin{array}{c}\text { Strongly } \\
\text { Agree }\end{array}$ & Agree Undecided & Disagree & Total \\
\hline $\begin{array}{c}\text { 1- Writing journals was } \\
\text { difficult at the } \\
\text { beginning but now it is } \\
\text { interesting. }\end{array}$ & 50 & 10 & 0 & 2 & 62 \\
\hline $\begin{array}{c}\text { 2- Writing my daily } \\
\text { journal helped me } \\
\text { enrich my EFL } \\
\text { vocabulary. }\end{array}$ & 35 & 15 & 7 & 5 & 62 \\
\hline $\begin{array}{c}3-\text { Writing journals } \\
\text { helped me improve my } \\
\text { English grammar. }\end{array}$ & 38 & 16 & 5 & 3 & 62 \\
\hline $\begin{array}{c}\text { 4- Writing journals } \\
\text { helped me improve my } \\
\text { writing fluency. }\end{array}$ & 36 & 11 & 10 & 5 & 62 \\
\hline
\end{tabular}

\begin{tabular}{|c|c|c|c|c|c|}
\hline $\begin{array}{c}5-\mathrm{I} \text { am planning to } \\
\text { continue writing my } \\
\text { journals regularly. }\end{array}$ & 31 & 12 & 17 & 2 & 62 \\
\hline
\end{tabular}

Table 13 displays a summary for students' opinions and attitudes toward their journal writing experience. As shown in Table 4, and through 60 positive responses to question 1, 50 positive responses to question 2,54 positive responses to question 3 and 47 positive responses to question 4, students' journal writing practice reflect cycle 2 students' interest towards this technique as well as their awareness of its worth in improving their vocabulary, grammar and fluency. Such a high response rate encountered through the data regarding students' continuity of journal writing after the intervention is stopped, where 43 out of 62 students claim to continue writing their journals can be considered a success to the intervention.

Q1- Writing journals was difficult at the beginning, but now it is interesting.

Table 14: Students` Opinion about Journal Writing

\begin{tabular}{|c|c|c|c|}
\hline Strongly Agree & Agree & Undecided & Disagree \\
\hline 50 & 10 & 0 & 2 \\
\hline $80.65 \%$ & $16.13 \%$ & $0.00 \%$ & $3.23 \%$ \\
\hline
\end{tabular}

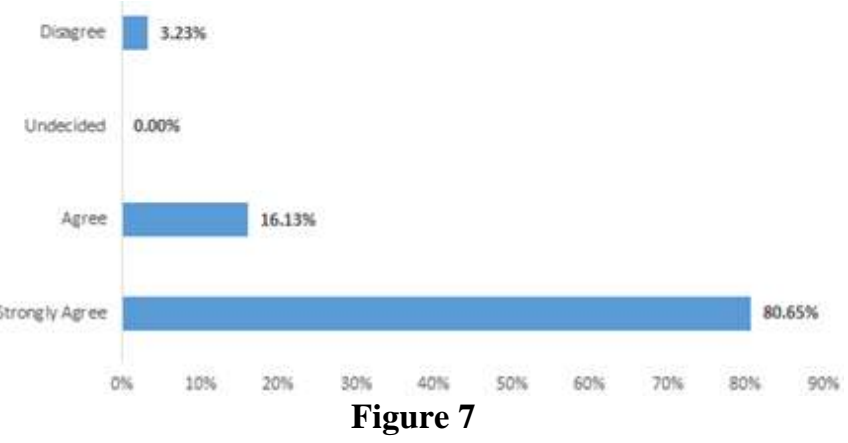

Table 14 and figure 6 show the students' opinions toward the task of writing a journal. 50 students $(80.65 \%$ of the participants) strongly agree and 10 students $(16.13 \%$ of the participants) agree that journal writing was difficult at the beginning, but by time it became interesting. On the other hand, 2 students (3.23\% of the participants) find that journal writing is an easy task from the beginning. The results in the table and figure mentioned above prove that cycle two students were not used to write in English regularly because the majority faced difficulties in writing their journals at the beginning of the intervention, but fortunately turned to be interesting at the end of the intervention.

2- Writing my journals helped me enrich my EFL vocabulary.

Table 15: Vocabulary Improvement

\begin{tabular}{|c|c|c|c|}
\hline Strongly Agree & Agree & Undecided & Disagree \\
\hline 35 & 15 & 7 & 5 \\
\hline $56.45 \%$ & $24.19 \%$ & $11.29 \%$ & $8.06 \%$ \\
\hline
\end{tabular}


International Journal of Science and Research (IJSR)

ISSN (Online): 2319-7064

Index Copernicus Value (2016): 79.57 | Impact Factor (2017): 7.296

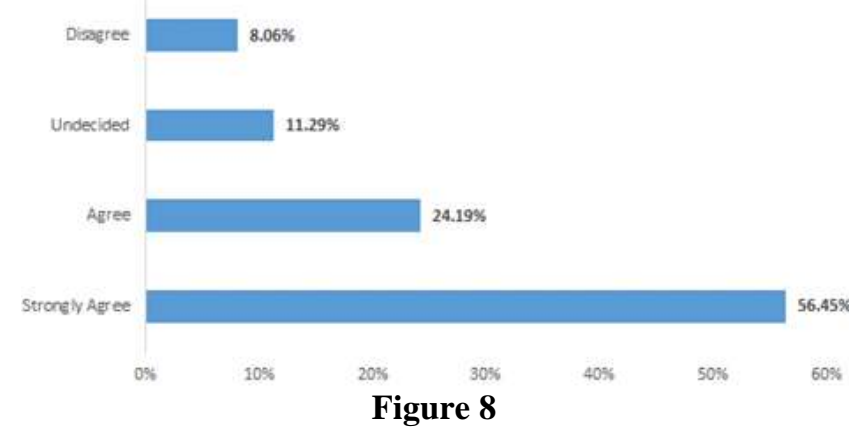

Concerning the benefits of journal writing technique in terms of vocabulary, table 15 and figure 7 show that 35 students $(56 \%)$ and 15 students $(24.19 \%)$ of the participants strongly agree and agree respectively that this technique helped them improve their EFL vocabulary. On the other hand, we find that 7 students $(11.29 \%)$ are undecided and 5 students disagree that journal writing helped them improve their EFL vocabulary. Accordingly, we have been able to prove that the majority of students in cycle two could benefit from writing journals regularly regarding vocabulary.

3- Writing journals helped me improve my English grammar.

Table 16: Grammar Improvement

\begin{tabular}{|c|c|c|c|}
\hline Strongly Agree & Agree & Undecided & Disagree \\
\hline 38 & 16 & 5 & 3 \\
\hline $61.29 \%$ & $25.81 \%$ & $8.06 \%$ & $4.84 \%$ \\
\hline
\end{tabular}

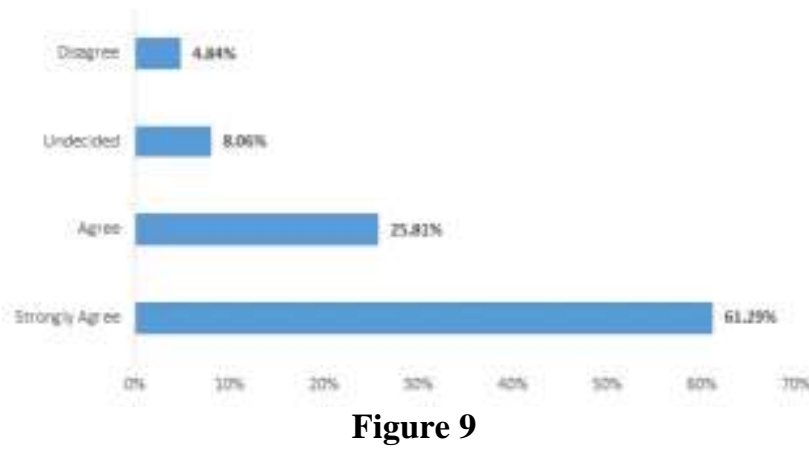

Table 16 and figure 8 show that the majority of students have improved their grammar skills through writing their journals regularly. $38(61.29 \%)$ and 16 (25.81\%) participating students strongly agree and agree respectively that journal writing technique helped them to develop their grammar skills while 5 students $(8.06 \%)$ are undecided and 4 students $(4.84 \%)$ disagree that journal writing helped them to improve their grammar skills.

4- Writing journals helped me improve my writing fluency.

Table 17: Writing Fluency Improvement

\begin{tabular}{|c|c|c|c|}
\hline Strongly Agree & Agree & Undecided & Disagree \\
\hline 36 & 11 & 10 & 5 \\
\hline $58.06 \%$ & $17.74 \%$ & $16.13 \%$ & $8.06 \%$ \\
\hline
\end{tabular}

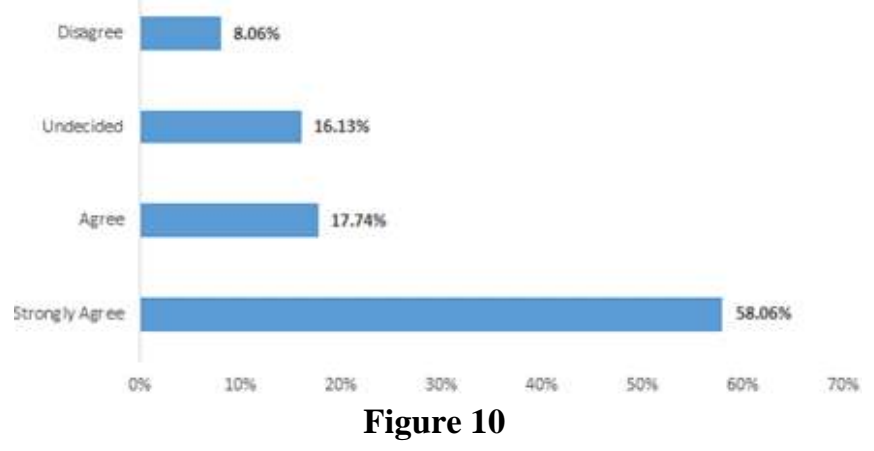

Table 17 and figure 9 show that the majority of students claim that their writing fluency is developed through writing their journals regularly. $36(58.06 \%)$ and $11(17.74 \%)$ of the participants strongly agree and agree respectively that journal writing technique helped them to generate more ideas while 10 students $(8.06 \%)$ only are undecided and 5 students $(4.84 \%)$ disagree that journal writing help them improve their writing fluency.

5- I am planning to continue writing journals regularly.

Table 18: Journal Writing Continuity

\begin{tabular}{|c|c|c|c|}
\hline Strongly Agree & Agree & Undecided & Disagree \\
\hline 31 & 12 & 17 & 2 \\
\hline $50.00 \%$ & $19.35 \%$ & $27.42 \%$ & $3.23 \%$ \\
\hline
\end{tabular}

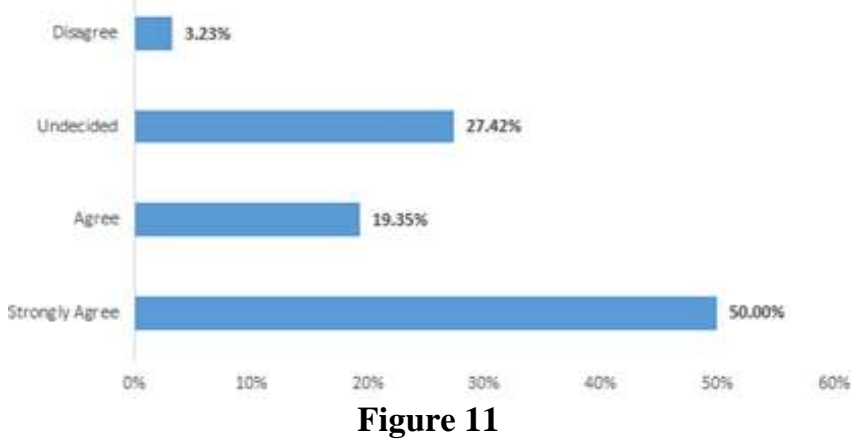

Table 18 and figure 10 show that the majority of students plan to continue writing their journals regularly after the intervention. $31(50.00 \%)$ and $12(19.35 \%)$ participating students strongly agree and agree to continue writing their journals regularly while 17 students $(27.42 \%)$ are undecided and 2 students $(3.23 \%)$ disagree to continue writing their journals regularly. These encouraging results show us that journal writing helped students to be habituated to writing which is recommended in EFL learning.

\section{Observation Results}

Evidences of observation, discussions and conversation explain the results more. Analyzing the teachers' and the researcher's observation notes concerning students' reactions during the intervention of journal writing technique to investigate the impact of journal writing on student attitudes was not an easy task. Many activities were conducted during the discussion sessions. During one of the discussion periods, the teacher asked the students whether they are enjoying writing their journals or not. The majority of the students expressed that they were enjoying it; for example one girl said, "I like writing journals most because I

\section{Volume 7 Issue 5, May 2018}




\section{International Journal of Science and Research (IJSR) \\ ISSN (Online): 2319-7064}

Index Copernicus Value (2016): 79.57 | Impact Factor (2017): 7.296

can choose the topic and can write a lot, every week," and a boy said, "It is interesting to write freely with no worries of grading, limited time, number of lines and language mistakes", while Rania said, "What is awesome about journal writing is that you do not have to think about mistakes you just focus on in class writing."On the other hand, one of the students mentioned that it's a waste of time since they have many assignments to prepare every day and another one said that it is frustrating to write three times a week specially that he has no time to practice his sport hobby while the third stated that after he finishes his studies he used to watch TV but writing a journal three times a week prevented him from this pleasure. Answering another question asked by the teacher was about the time spent on writing their journals; some students mentioned that it took them an hour while the majority needed between twenty and forty minutes. More questions were asked related to the strategies students used to overcome the difficulties they faced while writing their journals. One student at the back mentioned that she used a dictionary to look for needed vocabulary. As for the naughtiest student who claimed that he referred to his mom whenever he needed a new word. What was funny is Sami's strategy of calling a classmate to ask for a meaning of a word.

Concerning the teachers' Monday feedback, most of the students found that the teacher correction of their common mistakes was beneficial while her written feedback on their journals was not satisfying as it was more encouraging than highlighting their mistakes and correcting them. What was obvious through observation was students' positive reactions to interact and express their points of view. Furthermore, the students enjoyed the discussion sessions where they proved to be good listeners focused on the content of the read journals in class and showed interest in commenting and claiming their feedback. Students were very proud of their writing products in a way that all wanted to read their journals at a time which obliged the teacher to set a schedule for the three sections so that every student could have a chance to read his journal during the intervention. In general, students interacted enthusiastically, and looked eager to know that they were improving in writing.

Concerning students` improvement the teacher claimed that the first three weeks the journals were very short and did not exceed 5 lines specially in $\mathrm{G} 4$. She added while time was passing students in the three sections were able to introduce new words, more ideas and less grammar mistakes. Comparing students journals written in their copy books the researcher could realize that they have improved in structuring their sentences, organizing their ideas and expanding their information with details but that was not enough as long as they still have spelling mistakes subject verb agreement faults and more concerning grammar, mechanics and structure. Both the teacher and the researcher agreed that if students continue to write their journals regularly for one more year they will become good writers.

Through analyzing the results of the attitude questionnaire and the observation notes, we can conclude that the journal writing technique affected students' attitudes and writing skills positively which means that question three is answered.

\section{Discussion}

The main purpose of the present study was to determine whether journal-writing technique would lead to the development of cycle two students' writing scores and their attitude toward the writing skill. The study aimed as well at exploring the differences occurred between groups attributed to class and gender. As seen above, 62 students were taken as a sample from grades 4, 5 and 6 classes, with no missing values in the students' pre and posttests, so the number of students stayed fixed in the pre and the post-test.

The technique conducted in this study has been found to be effective of arousing interest in writing, which, at the same time, developed students' writing achievement, grammar, vocabulary and fluency.

The findings of the present study provide further confirmation for the results of previous studies about the effect of journal writing: Peyton,(2000); Myers,(1987); Shuy, (1981); Megnan, (1985); Mccarthy,(1991); Peyton \& Syoum, (1988); Staton,(1984); Mirhosseini, (2009); Liao \& Wong, (2001); Barjesteh, Vaseghi, \& Gholami, (2011). Similar to Morel (2010) Barjesteh et al, (2011); Fitriana, (2009), our findings indicated that our students have gained better writing scores after conducting the journal writing technique for 12 weeks. When the pre $\backslash$ post test scores were analyzed, it was clear that less number of failures and higher scores compared to their pre test scores were noticed; $\mathrm{G} 4$ had 5\% failures in the pre- test that turned to be $0 \%$ in the posttest, G 5 had $18.75 \%$ failures that turned to be $6.25 \%$ in the post test and G $630 \%$ failures turned to be $10 \%$. Such a significant improvement implies that our students were able to write when the right teaching technique is implemented. Nonetheless, the results of the posttest conducted after the students' twelve-week practice of journal writing indicated a marked difference in the three classes by the students. The difference in the scores implying that the writing pace of the students in all classes improved to a higher extent than those in the pretest where results showed that G5 mean scores increased around 10 scores, G6 mean scores increased around 7 scores and grade four approximately 4 scores. Similarly, the female students demonstrated better improvement in their writing than males in grades 4 and 6 to reach $9.56 \%$ and $16.26 \%$ respectively, while in grade 5 the males showed a rate of achievement equals to $17.01 \%$ compared to females`achievement rate $12.36 \%$.

Apparently similar to Barjesteh, Vaseghi \& Gholami (2011), who emphasized journal writing to have a significant impact on EFL learners' attitudes towards writing where students can write freely without fear of being evaluated, our students have developed their writing skills and attitudes during the intervention of journal writing technique. When students' responses to the attitude questionnaire were analyzed, it was obvious that the participants were aware of their improvement in grammar, fluency and vocabulary skills which were also established statistically in the qualitative analyses of the students' responses in the questionnaire. Similar to Ghahremani-Ghajar \& Mir Hossseini's (2005)and Huang (2010), the study showed through teachers' and researchers' notes that journal writing provided EFL students with critical self-reflection ability and increased 


\section{International Journal of Science and Research (IJSR) \\ ISSN (Online): 2319-7064}

Index Copernicus Value (2016): 79.57 | Impact Factor (2017): 7.296

their motivation to write without fear and speak with selfesteem. Although, this process revealed a number of crucial findings, our sample seemed to have strongly agreed that they have experienced difficulties in writing their journals at the beginning but turned to be interesting at the end. Parallelto Hashemi Z, Amerian M. (2011) study results, the teacher, the researcher and the majority of our participants could notice the improvement in grammar, vocabulary and fluency skills from their journal writing experience. What was interesting is that more than half of the students claimed that they will continue writing their journals regularly after the intervention is stopped. Such results can tell that practicing journal writing regularly can lead students to get accustomed to writing which is recommended to improve EFL students' writing skills.

Consistent with Payton (2000) Fitriana (2009) and Hidayat (2011), Ningrum, Rita \& Hastini (2013),our students' writing journals focus on meaning and issues of their interest rather than form. Similar to Thomas (2003) results, the students made positive changes in their writing achievement, which means that they could overcome their writing problems through practicing and discussing without the teachers' focus on their mistakes. Teachers in these studies did not correct errors they only wrote comments to encourage students so they kept on writing. Following their procedures in this study, journal writing is when students write freely, without focusing on form or time while the teacher's role is limited to praising, explaining students' common mistakes, discussing, observing, and monitoring which served as an indirect guidance for students to know their mistakes and correct them.

Referring to the observation notes analysis, we found that when students were asked about the differences between writing in class and writing journals at home the majority encountered problems of timing, vocabulary, grammar mistakes and grading when writing in class. On the contrary, students expressed their interests in writing their journals away from grading and timing where they could write about any topic and had enough time to look for the right word and the right idea, which helped them develop their writing skills. Moreover, what was deduced through their reactions, is consistent with the results of Ghahremani - Ghajar \& Mir Hossseini's (2005)study who found postulated that journal writing provided EFL students with confidence and motivation to write regularly. It was clear for the teacher and the researcher that students were enjoying writing when they were not overwhelmed by monitoring their language errors. Thus, once the barriers of class writing restrictions were broken, students were able to generate more ideas and improve their level of writing fluency. What seems to be very effective is the praising and encouraging comments that motivated students to accomplish their writing tasks and have better scores in their posttest regardless of their accuracy levels. Not only had the follow up, the discussions the praise comments and instructions affected the students' fluency but their attitude, grammar, and vocabulary were affected too. Finally, the present study indicated that the period of 12 weeks practicing journal writing helped increase EFL cycle two students' English writing achievement and their attitude to writing. These findings highlight the importance of focusing on English journal writing technique, rather than having only writing sessions guided by accuracy, time and scores in EFL classes. Nevertheless, the limitations to over generalizing these findings should be avoided as the study is limited to cycle two students at a private school in Beirut Lebanon. Further studies are required to overcome the limitations of the present study and to produce more convincing evidence of the importance of focusing on journal writing in EFL curriculum. At the end nothing to say more than that our findings related to our students' writing progression due to the intervention of journal writing added an extra technique that can take place in teaching writing for cycle two students.

\section{Conclusion}

As noted earlier, the aim of this study was to investigate the impact of the journal writing technique on EFL cycle two students writing achievement and attitude. Generally speaking, the students displayed positive attitudes towards journal writing, as they highly appreciated experiencing the process of journal writing offered to them by their instructors. The study pinpointed the fact that journal writing is an efficient technique to improve students' writing skills when practiced in a free environment away from scoring and timing. The study proved by statistics that writing journals three times a week encouraged students to write more and have better writing achievement. Students' attitude toward this technique of writing was positive as they expressed its benefits in developing their writing fluency and generating ideas, grammar, vocabulary and continuity to write. Thus, the study emphasized the writing skill as one of the basic foreign language skills in EFL teaching and learning that requires the right instruction with effective proficiency to guide students and help them improve their writing skills. Moreover, the journal writing technique motivated students to write freely and regularly about topics of their preference that helped them achieve better scores. Similar to many mentioned researchers, the students made positive changes in their writing achievement, which means that they could overcome their writing problems through practicing and discussing.

A straight forward implication of the findings is that journal writing can be a very productive and creative writing technique for cycle two male and female students. The different questions arose in students' minds while writing their journals led them to deeper thinking and searching for answers to their questions that in turn developed students' learning. Thus writing journals fostered students to ask many questions related to foreign language grammar, vocabulary, expressions or even sentence structure that helped them to write their journals' content and develop their EFL writing skill. Furthermore, we can say that the process followed in this study emphasized journal writing, where students wrote freely without fear of being evaluated or restricted to a specific topic or specific time. The process followed in this study paved the way for students to develop their writing skills and their attitude toward writing. The success of the journal technique was reflected through the significant results of EFL learners' achievement and attitudes. Finally, the present study indicated that the period of 12 weeks practicing journal writing helped increase EFL

\section{Volume 7 Issue 5, May 2018}




\section{International Journal of Science and Research (IJSR) \\ ISSN (Online): 2319-7064}

Index Copernicus Value (2016): 79.57 | Impact Factor (2017): 7.296

cycle two students' English writing achievement and their attitude to writing. These findings highlighted the importance of focusing on journal writing technique, rather than having only writing sessions guided by accuracy, time and scores in EFL classes. Not to forget that discussion was one of the central elements in EFL teaching journal writing that encouraged students to interact with each other and gain new ideas, recognize their mistakes and develop communication as well as writing. It is an aspect that needs special attention and instruction to provide students with effective proficiency. Thus, it is suggested that writing class instructors should be highly encouraged to provide the students with adequate instructions on the task of journal writing before assigning it to a writing class, and finding academic solutions to time and topic constraints. It is hoped that this paper would offer instructors dealing with EFL learners the suitable writing strategies, one of which, is journal writing, which arises students' motivation.

Nevertheless, the limitations to over generalizing these findings should be avoided as the study is limited to cycle two students at a private school in Beirut Lebanon. Further studies are required to overcome the limitations of the present study and to produce more convincing evidence of the importance of focusing on journal writing in EFL contexts. Finally, it is hoped as well that this paper suggests a considerable addition to the existing literature as far as writing strategies are concerned.

\section{References}

[1] Absalom, M. \& Leger, D. (2011). Reflecting on reflection: Learner perceptions of journals and blogs in tertiary language study. Arts and Humanities in Higher Education, 10(8),189- 211.

[2] Bagheri, S. \& Pourgharib, B. (2013). An investigation of the effect of journal writing on EFL learners' oral production. International Research Journal of Applied and Basic Sciences, 4 (11), 3520-3525.

[3] Barjesteh, H.; Vaseghi, R. \& Gholami, R. (2011). The effect of journal writing on EFL college students' writing improvement and attitudes. International Conference on Languages, Literature and Linguistics IPEDR, 26, 143-147.

[4] Bluestein, J. (2004). Practical strategies for working successfully with difficult students. Bellevue, WA: Bureau of Education and Research.

[5] Corpus, J.; Ogle, C. \& Love-Geigner, K. (2006). The effects of social-comparison versus mastery praise on children's intrinsic motivation. Motivation and Emotion, 30,335-345

[6] Curtis, A., \& Bailey, K. M. (2009). Journal studies: Research Digest. OnCUE Journal, 3(1),67-85.

[7] Daiker, D., A. (2011). Learning to praise. In I. L. Clark concepts in composition: Theory and practice in the teaching of writing (2nd Ed.). New York: Routledge.

[8] Elbow, P. (1998). Writing with power: Techniques for mastering the writing process (2nded.) Oxford: Oxford University.

[9] Ferris, D. (2002). Treatment of error in second language writing classes. Ann Arbor, MI: Univerisyt of Michigan Press.
[10] Ferris, D. (2004). The "grammar correction" debate in L2 writing: Where are we, and where do we go from here? (and what do we do in the meantime...?) Journal of Second Language Writing, 13,49-62.

[11] Fitriana, D. (2009). The students' ability in creating written recount texts. $\mathrm{PhD}$ Thesis. University of Negeri Semarang. Indonesia.

[12] Ghahremani-Ghajar S, Mirhosseini SA. 2005. English Class or Speaking About Everything Class: Dialogue Journal Writing as a Critical Literacy Practice in an Iranian High School. Language, Culture and Curriculum, 18(3): 286-299.

[13] Goldstein, L. (2004). Questions and answers about teacher written commentary and student revision: Teachers and students working together. Journal of Seocnd Language Writing, 13,63-80.

[14] Haimovitz, K.; Corpus, J. H. (2011). Effects of a person versus process praise on student motivation: Stability and change in emerging adulthood. Educational Psychology: An international journal of experimental educational psychology, 1-15 I First Article.

[15] Hamp-Lyons, L. \& Heasly, B. (2006). Study writing (2nd Ed.). Cambridge: Cambridge University Press.

[16] Hashemi Z, Amerian M. 2011. The Impact of Journal Writing on the Correct Use of Grammar among EFL Students of Rafsanjan Universityof Medical Science, IRAN, pp.48-59.

[17] Hidayat, T. (2011). The use of journal writing method to improve students' writing recount text ability. Bachelor's Degree, Semarang State University.

[18] Hiemstra, R. (2001). Uses and benefits of journal writing. New Directions for Adult and Continuing Education, 90,19-26.

[19] Huang, J. A. (2010). A case study of the influence of free writing on writing fluency and Confidence of EFL college-level students. Second Language Studies, 28(2),97-134

[20] Johnson, A. (2002). Journal Writing for an audience. Modern English Teacher, 11(2),46-50.

[21] Kirkgoz, Y.(2009). Exploring growth in vocabulary learning through learner journals. Proceedings of the 10th METU ELT Convention.

[22]Lagan, J. (2000). College Writing Skills. London: Longman.

[23] Lipnevich, A.A. \& Smith, J.K. (2008). Response to assessment feedback: The effects of scores, praise, and source of information. Educational Testing Service.http://www.ets.org/reserch/content.html..

[24] Marefat, F. (2002). The impact of journal analysis on teaching/learning writing. RELC Journal, 33(1), 101121.

[25] McDonough, J., McDonough, S. (1997). Research methods for English language teachers. Arnold, London.

[26] Myers M. 1987. The Shared Structure of Oral and Written Language and Implications of Teaching Writing, Reading and Literature. In: J. R.Squire (Eds.), The Dynamics of Language Learning,18(1): 121-146.

[27] Ningrum, V., Rita, F. \& Hastini (2013). E-Journal of English Language Teaching Society (ELTS), 1 (1),1-13.

[28] Nunan, D. (1992). Research methods in language learning. Cambridge: Cambridge University Press. Patterson, D. (2014). Using writing journals as a means 


\section{International Journal of Science and Research (IJSR) \\ ISSN (Online): 2319-7064 \\ Index Copernicus Value (2016): 79.57 | Impact Factor (2017): 7.296}

of increasing EFL writing fluency. Proceedings of ICLC 2013: The 5th International Conference on Language \&Communication, 81-91.

[29] Peyton JK. 1993. Dialogue Journals: Interactive Writing to Develop Language and Literacy. ERIC Digest. Washington, DC: ERIC Clearinghouse on Languages and Linguistics. (EDRS No.ED 354 789).

[30] Porter, A.; Goldstein, L.; Leatherman, J. \& Conrad, S. (1990). An ongoing dialogue: Learning logs for teacher preparation. In J. Richards \& D. Nunan (Eds.) Second Language Teacher Education. Cambridge: Cambridge University Press.

[31] Porter, P.; Goldstein, L.; Leatherman, J. \& Concad, S. (1996). An ongoing dialogue: Learning language for teacher preparation-SLT.

[32] Richards, K. (1992). Pepys into a TEFL course. ELT Journal, 46(2),144-152.

[33] Richards, J. \& Lockhart, C. (1996). Reflective teaching in second language classroom. Cambridge: Cambridge University Press.

[34] Rubin, J. (2003). Journal writing as a process: simple, useful, powerful. Guidelines, 25(2),10-14.

[35] Safitri, Y. (2011). The effect of using journal on the eighth grade students' achievement in writing a recount text at SMPN 2 BANGIL. PHD Thesis. Jember University.

[36] Shuy, RW. (1981). A Holistic View of Language. Research in the Teaching of English, 15: 101-111.

[37] Schunk, D.H. \& Zimmerman, B.J. (2012). Motivation \& self-regulated learning: Theory \& Research and applications. New York: Taylor \& Francis Group.

[38] Straub, R. (1997). Students' reactions to teacher comments: an exploratory study. Research in the Teaching of English, 31(1),91-119.

[39] Staton, J. (1984). Thinking Together: Interaction in Children's Reasoning. In C. Thaiss \& C.Suhor (Eds.), Speaking and Writing, K-12 (pp.144-187). Champaign, IL: National Council of Teachers of English.

[40] Truscott, J. (2004). Evidence and conjecture on the effect of correction: A response to Chandler. Journal of second Language Writing, 13,337-343.

[41] Truscott, J. (2007). The effect of error correction on learners' ability to write accurately. Journal of Second Language Writing, 16,255-272.

[42] Truscott, J. \& Hsu, A. (2008). Error correction, revision and learning. Journal of Second Language Writing, 17,292-305.

[43] Tuan, L. T. (2010). Enhancing EFL learners' writing skill via journal writing. English Language Teaching, 3(3), 81-88.

[44] Wafa, A.; Syafei, M. \& Riyono, A. (2010). Keeping journal writing to improve the writing ability of the tenth grade students of SMA NI Jekulo Kudus in the academic year 2009/2010. ISSN: 1979-6889.

[45]Zittoun, T.; Gillespie, A. (2011). In E. Abbey \& S. Surgan, (eds). Using journals and self writings as data in Psychological research. Emerging Methods in Psychology: History \&theory of Psychology. Transaction Publishers, New Brunswick, New Jersey, USA. 